\title{
X-cell disease of cod Gadus morhua from the North Sea and Icelandic waters
}

\author{
V. Dethlefsen*, T. Lang, U. Damm \\ Bundesforschungsanstalt für Fischerei, Außenstelle Cuxhaven, Deichstraße 12, D-27472 Cuxhaven, Germany
}

\begin{abstract}
Tumour-like swellings in the pseudobranchial region have been described to occur in gadidae of many marine areas. They are associated with the presence of $\mathrm{X}$-cells of unknown origin. Their occurrence in cod Gadus morhua L in the North Sea has regularly been studied since 1982, and additionally from 1991 to 1993 in Icelandic nearshore waters. Histologically, the lesions found in Icelandic cod were identical to those previously described for North Sea cod. In Icelandic cod, lytic or disintegrating stages were more frequent than previously described. For the North Sea, a considerable long-term variability of the prevalence of X-cell disease in cod was recorded ranging from 0 to $4.6 \%$, with a maximum in January 1989. The variability was different in different areas of the North Sea, and was compared with the fluctuations of numbers of cod caught per hour. Lengths of cod afflicted with the disease in the North Sea do not normally exceed 40 to $50 \mathrm{~cm}$ (predominantly age classes II and III are affected). No such restriction was found in Icelandic waters where cod up to $100 \mathrm{~cm}$ length were found to be affected. In Icelandic waters, affected fishes were significantly smaller than their healthy compatriots at a given age. There was no density dependence for the infestation of cod in the material tested for the North Sea. There is a need for further studies on the impact of the disease on the growth of cod, and the etiology of X-cell diseases needs to be elucidated.
\end{abstract}

KEY WORDS: Cod Gadus morhua - X-cell disease - Pseudobranchial pseudotumours · North Sea . Iceland · Epidemiology - Impact on growth

\section{INTRODUCTION}

The X-cell disease of cod Gadus morhua L. (previously often reported as pseudobranchial tumours) was first detected by Peyron \& Thomas (1929) in the northwest Atlantic off Newfoundland. The disease was further described off the western coast of Norway (Lange 1973). Prevalences of up to $4.0 \%$ were found at the coast and continental shelf of eastern Canada (Morrison et al. 1979), and $2.0 \%$ in Canadian waters around Nova Scotia (Morrison et al. 1982). Egidius et al. (1981) observed prevalences between 0.4 and $0.7 \%$ in cod

•E-mail: 101322.3467@compuserve.com from the Barents Sea. Watermann et al. (1982) provided information on the occurrence of the disease in the North Sea and the western Baltic Sea, and Anders \& Möller (1991) discovered it in cod in the German Wadden Sea.

$X$-cell pseudotumours are uni- or bilateral proliferations of the pseudobranches located in the upper palatine area and can easily be seen during the inspection of the mouth cavity.

The pseudotumours grow to the size of a walnut and cases occur where proliferations are externally visible on the upper edge of the operculum. The histology of $X$-cell disease of cod was investigated e.g. by Watermann \& Dethlefsen (1982), who found indications that the pseudotumours are instigated by a protozoan 
infestation causing xenotumours associated with the pseudobranch organ. Peters (1984) summarizes the histological findings pointing out that the ultrastructure of the spherical cells bears a remarkable similarity to that of X-cells in Pacific flatfish papilloma. He stated that the question of whether X-cells are transformed fish cells or parasitic protozoa is unresolved. A recent attempt to prove the protozoan etiology of the pseudotumours was unsuccessful (Watermann et al. 1994).

Diseases of cod are studied within the framework of routine fish disease surveys which commenced in 1980. First results for the occurrence of X-cell disease of cod of the North Sea are available for 1980 and 1981; these data refer to the German Bight (Watermann et al. 1982). Aftcr these ycars, stations covercd the wholc North Sea. In June 1991, 1992 and 1993, the study area was extended to Icelandic nearshore stations. In the following paper, results are presented on the histology of the disease in Icelandic cod as compared to findings in North Sea cod, and information is provided on the long-term variability of prevalences of X-cell pseudotumours in cod in the North Sea from 1982 to 1993 and on the regional distribution of affected cod in the North Sea and off Iceland.

\section{MATERIAL AND METHODS}

Sampling in the North Sea between $53^{\circ}$ and $57^{\circ} \mathrm{N}$ has been carried out since 1982 twice a year (January and May/June/July). For the purpose of studying regional effects, an arbitrary subdivision into 6 areas was made (see Fig 7). Cod Gadus morhua were sorted from bottom trawl catches. Either total catches were processed or representative subsamples were investigated when numbers of cod exceeded 250 haul $^{-1}$. After length measurement counted down to the nearest centimeter, head regions of the fishes were externally and internally inspected for the occurrence of pseudobranchial pseudotumours (PBT). The X-cell disease was recorded to be present after visual inspection revealed dcviations from the normal development of pseudobranches. All doubtful cases were verified by subsequent histological investigation. Four to six 1 h hauls were performed per station and from the results catches per hour were calculated. Otoliths from diseased cod were taken at Icelandic nearshore stations in June 1993. For the description of trends in different regions in the study area, the North Sea was divided into 6 subareas as depicted in Fig. 7. In order to condense length frequency data and results on the re-

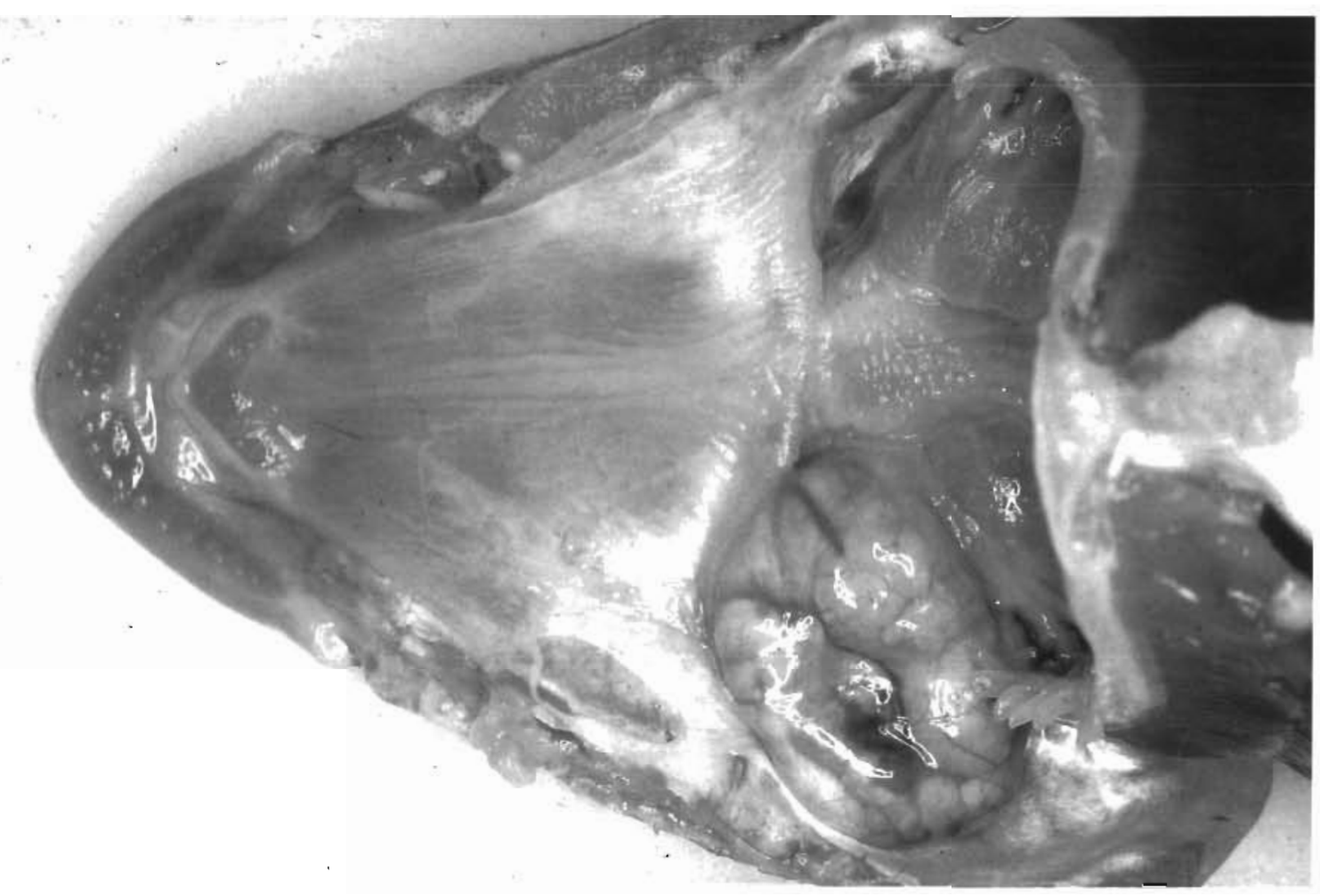

Fig. 1. Gadus morhua. Unilateral X-cell pseudotumour in the mouth cavity of cod. Lower jaw removed 
gional distribution of diseased fishes for the North Sea material, 2 yr averages were used, thus frequency distributions contain data from 4 cruises each. An analysis of variance was run, using a Generalized Linear Model approach (McCullagh \& Nelder 1983) with year, season, area and size entering as factors (for convenience, sizes were grouped in $5 \mathrm{~cm}$ intervals from 5 through $124 \mathrm{~cm}$ ). A binomial error distribution was assumed and a logit link function was applied.

For histological examination, samples of affected tissues were taken immediately after landing of catches and fixed in $10 \%$ buffered formalin. Routine histological examination was carried out using 5 to $8 \mu \mathrm{m}$ paraffin sections stained with Mayer's haematoxylin/eosin (HE; Romeis 1989).

\section{RESULTS}

\section{Morphology and histology}

The pseudobranch is a bilaterally paired organ embedded in the submucosal connective tissue of the pharyngeal wall (Takashima \& Hibiya 1995).

The gross lesions found in Icelandic cod were mostly restricted to the pseudobranchial region either occurring uni- or bilaterally as slight swellings or pronounced proliferations (Fig. 1). In severe cases, the pseudotumours were also located at the dorsolateral edges of the opercula or other regions of the head, including various parts of the mouth cavity. In a few affected specimens, PBT protruded into the gill arches and filaments (Fig. 2). Large pseudotumours were smooth and yellowish with dark red areas, and frequently they released liquid when dissected.

Histologically, in nonaffected pseudobranches an abundant distribution of blood capillaries is seen in the parenchyma encapsulated by thin connective tissue (Takashima \& Hibiya 1995).

The X-cell pseudotumours were mostly covered with normal epithelium and consisted mainly of masses of densely packed X-cells surrounded by darkly stained envelope cells separated into compartments by fibrous septae. Within these compartments, different stages of $\mathrm{X}$-cells were identified. Those in the vicinity of blood vessels often showed a light cytoplasm whilst those more distant were characterized by a dark and granulated cytoplasm. The nuclei in general were pale with a dark prominent nucleolus. The majority of X-cells were uninucleate; however, multinucleate cells occurred frequently revealing variations in size, shape, and number of nuclei (Fig. 3). In large pseudotumours, the compartments were often filled with necrotic X-cells with highly vacuolated or foamy cytoplasm and nuclei of irregular shape (Fig. 4).

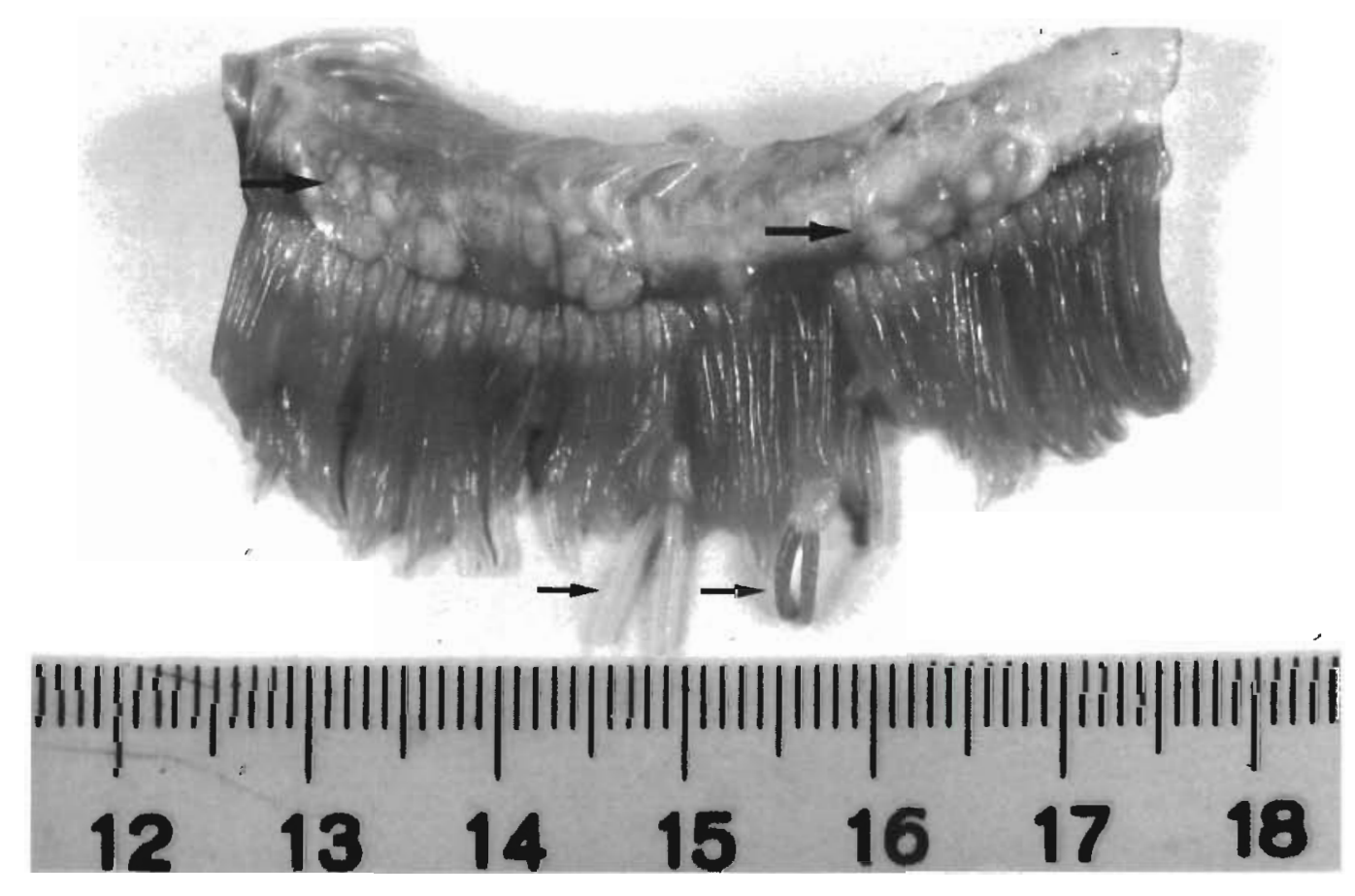

Fig. 2. Gadus morhua. Dissected gill arch of an Icelandic cod with X-cell disease. Large arrows indicate protrusions of the pseudotumour, small arrows infestation with Clavella adunca 


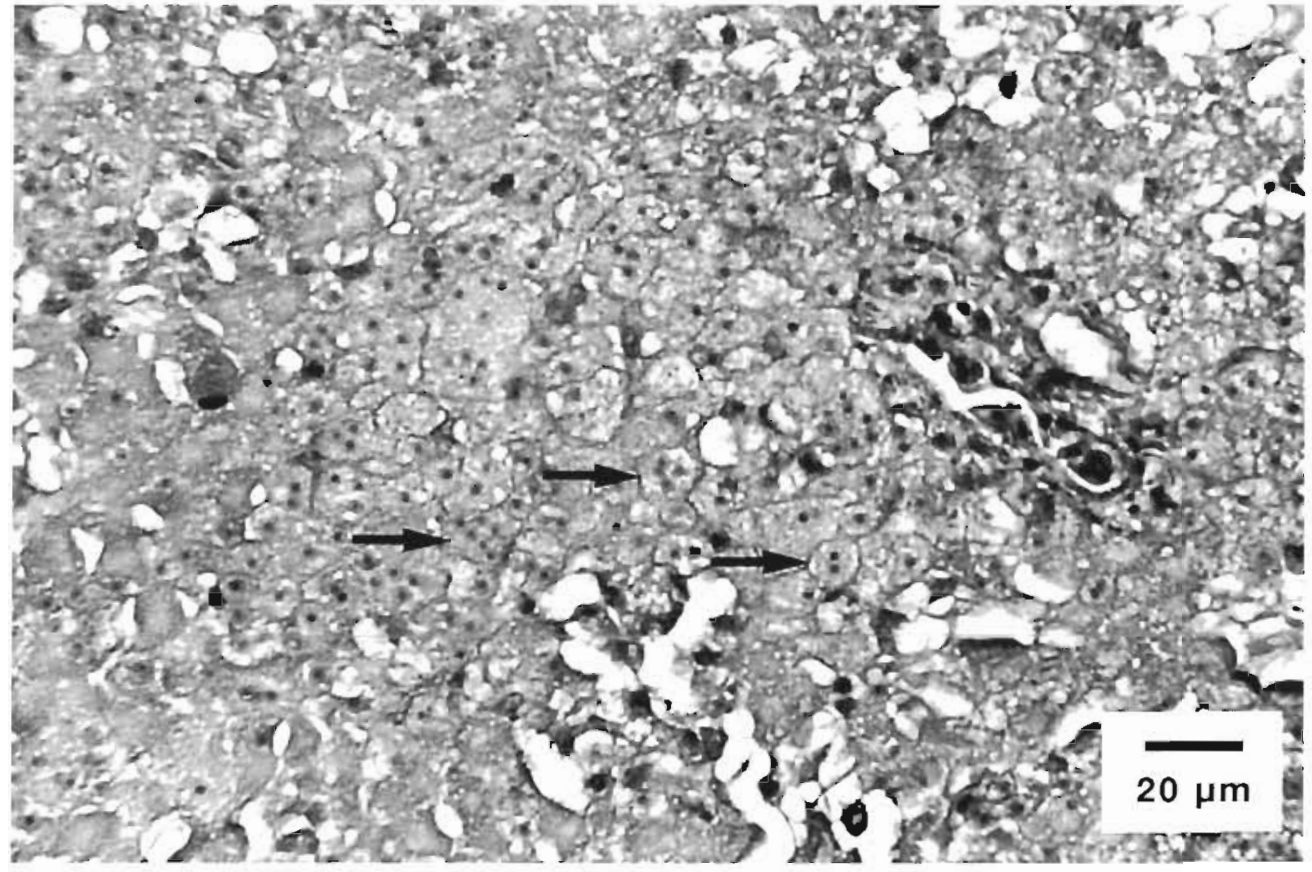

Fig. 3. Gadus morhua Xcells with dark, prominent nucleoli in pseudobranchial pseudotumours (PBT) of Icelandic cod. Arrows indicate multi-

nucleate X-cells (HE)

\section{Epizootiology}

North Sea stations were always located between $53^{\circ}$ and $57^{\circ} \mathrm{N}$ and between the British, Dutch, German, and Danish coasts. The long-term fluctuation of prevalences of cod afflicted with pseudobranchial tumours in this area is depicted in Fig. 5; $95 \%$ confidence lumits are included. Average prevalences between 1981 and 1993 varied from 0 to $4.6 \%$ with a maximum in January 1989. Prevalences fluctuated between 0 and $1 \%$ from 1982 to 1988 increasing thereafter to reach a maximum in January 1989. In the next $3 \mathrm{yr}$, prevalences fluctuated around $2 \%$, and in January 1991 the prevalence was $2.9 \%$, followed by a decrease towards the end of the perıd studied, which showed considerable variability. When prevalences are compared with the starting levels in January 1982, prevalence in May

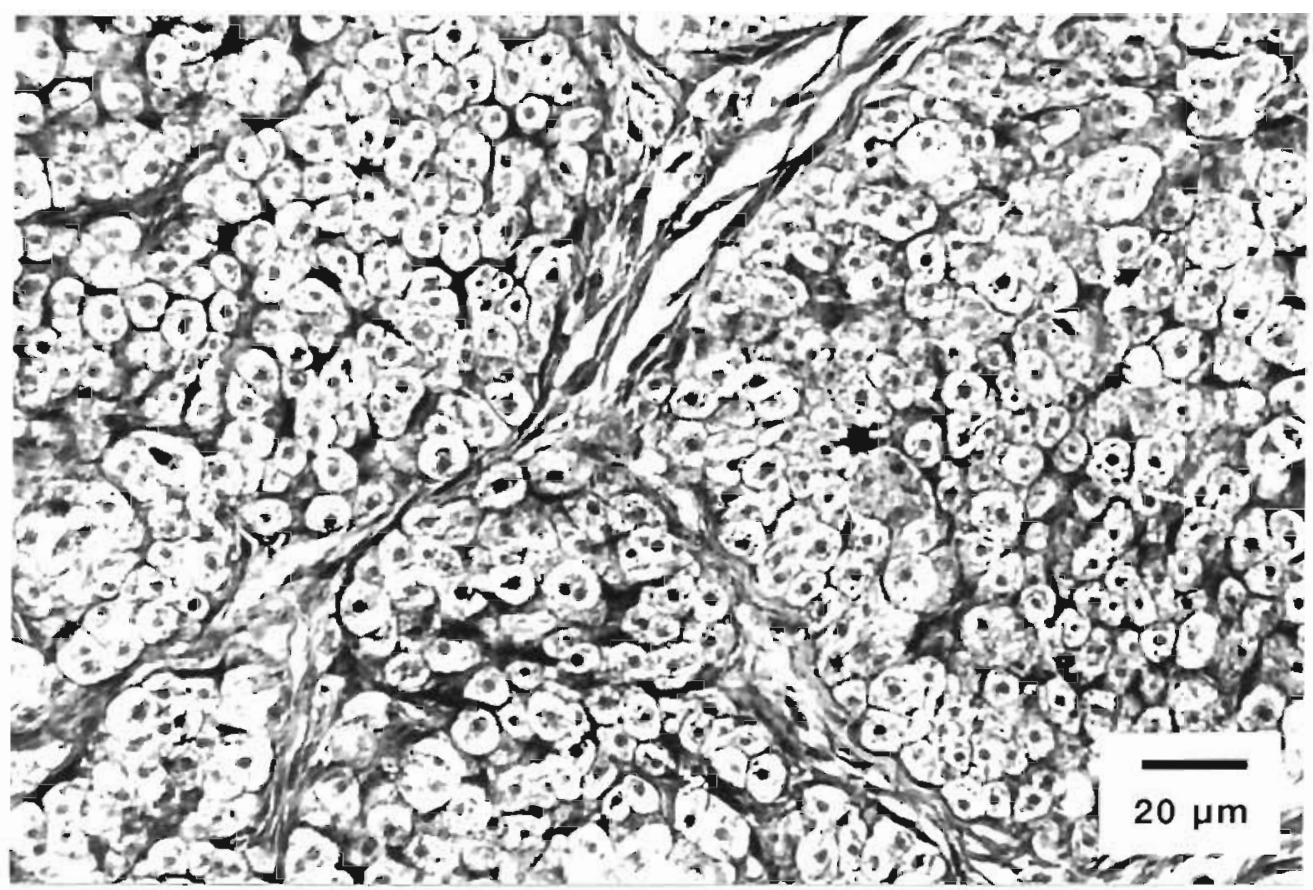

Fig. 4. Gadus morhua Necrotic X-cells in PBT of Icelandic cod with vacuolated/foamy cytoplasm and nuclel of i.regular shape surrounded by darkly stamed envelope cells and between fibrous septa (HE) 
1984 was significantly lower and infestation rates between May 1988 and May 1991 (with the exception of January 1990) were significantly higher (Table 1).

Table 1. Significance levels for differences of prevalences as compared to starting data in January 1982 (see Fig. 5). $\chi^{2}$ (Yates corrected), relative risk and $95 \%$ confidence limits of relative risk (CL)

\begin{tabular}{|lrrll|}
\hline Date & \multicolumn{1}{c}{$\chi^{2}$} & $\begin{array}{c}\mathrm{p} \\
\text { (2-sided) }\end{array}$ & \multicolumn{1}{l|}{$\begin{array}{l}\text { Relative } \\
\text { risk }\end{array}$} & $\mathrm{CL}$ \\
\hline May 1984 & 3.881 & 0.0488 & 0.0995 & $0.992-0.999$ \\
May 1988 & 7.627 & 0.0057 & 1.009 & $1.003-1.016$ \\
Jan 1989 & 33.068 & $<0.0001$ & 1.040 & $1.013-1.069$ \\
May 1989 & 10.692 & 0.0011 & 1.013 & $1.004-1.023$ \\
May 1990 & 8.963 & 0.0028 & 1.011 & $1.003-1.018$ \\
Jan 1991 & 13.239 & 0.0003 & 1.024 & $1.002-1.047$ \\
May 1991 & 6.851 & 0.0089 & 1.013 & $1.000-1.027$ \\
\hline
\end{tabular}
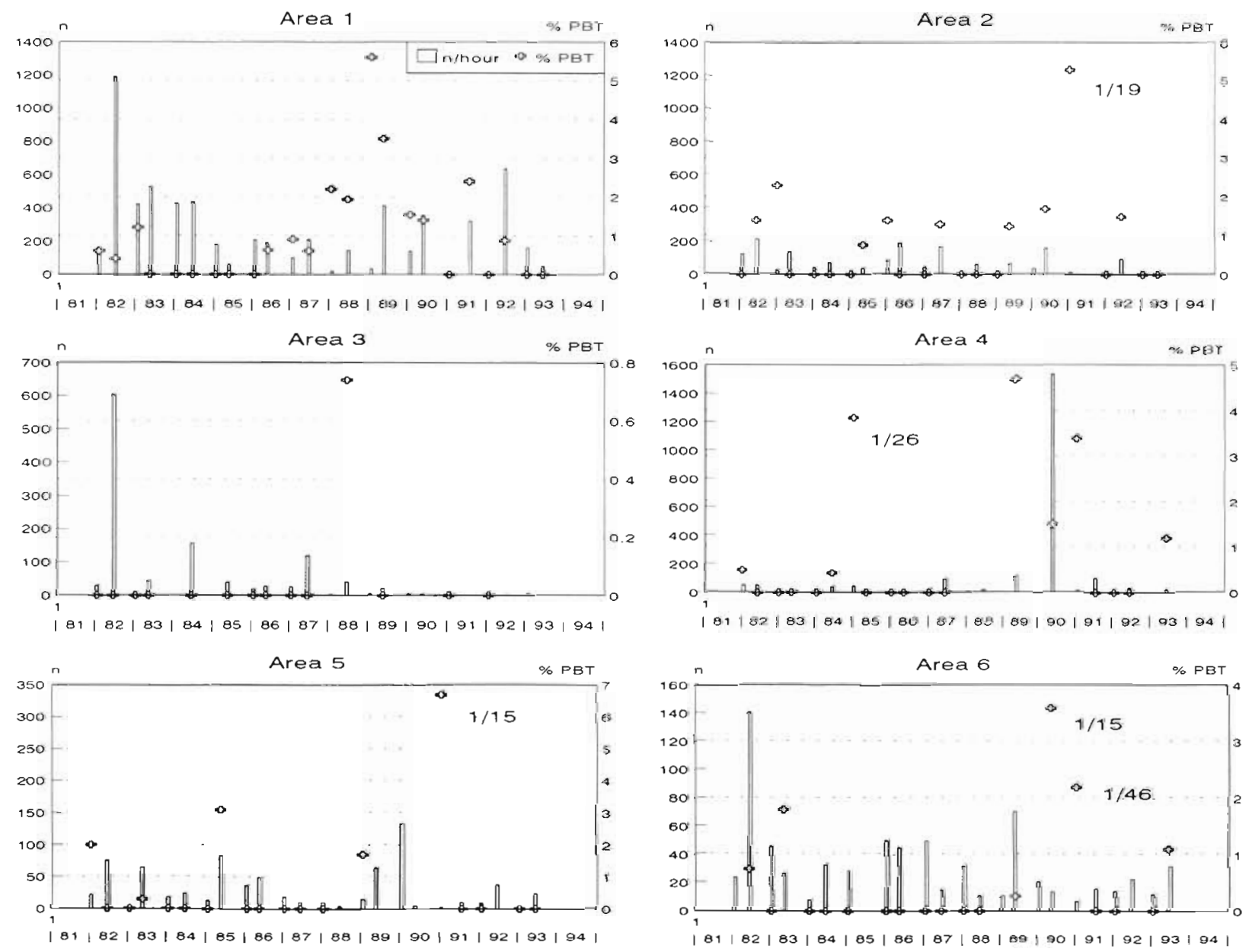

Fig. 6. Gadus morhua. Numbers of cod caught per hour and percentage of cod affected with PBT in 6 areas of the North Sea (for size and location of areas see Fig. 7). When less than 50 cod per cruise were investigated, numbers of diseased cod and numbers investigated (e.g. 1/19: 1 diseased cod out of 19 investigated) are given 

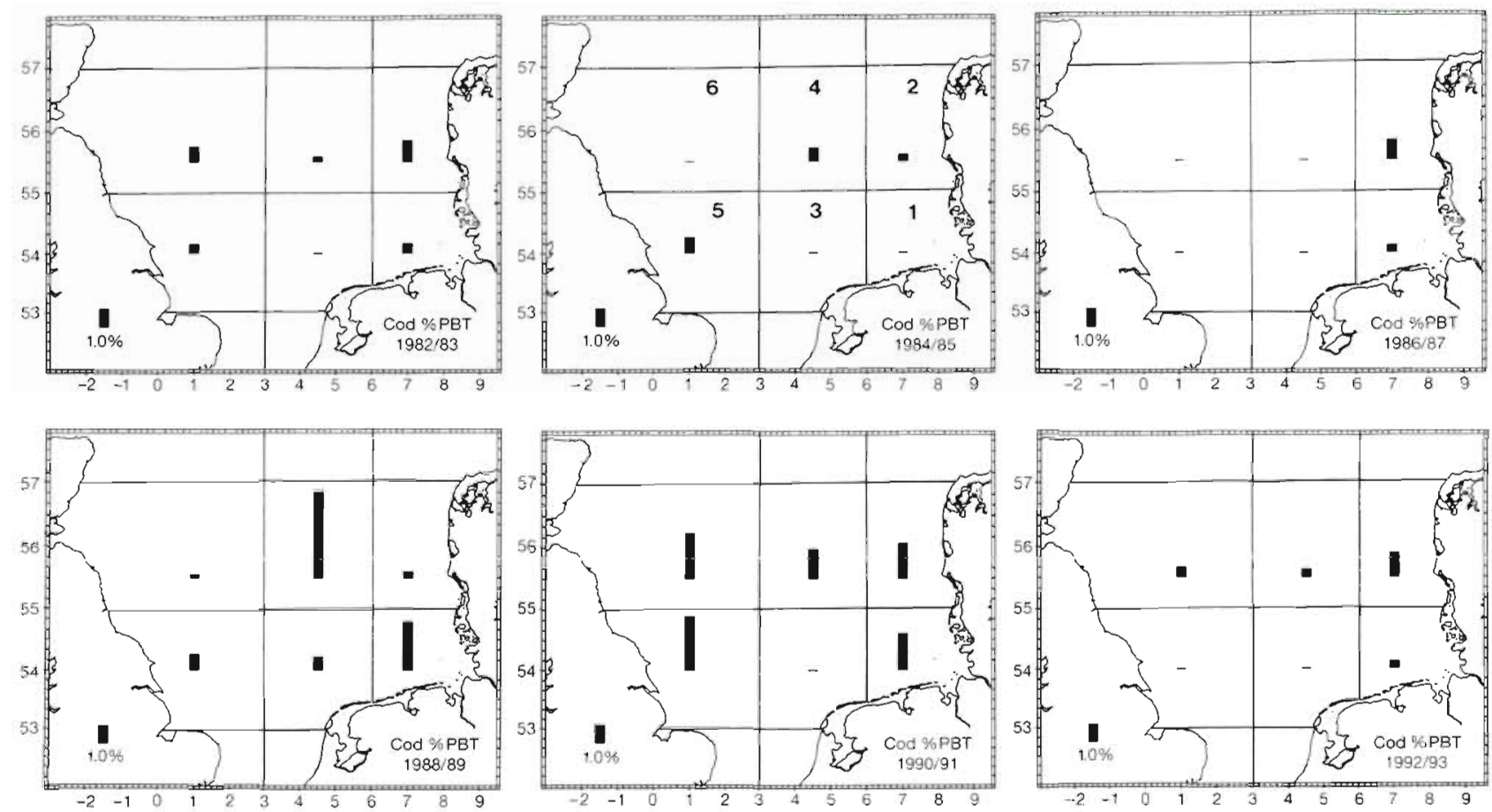

Fig. 7. Gadus morhua. Percentage of infestation with PBT in 6 areas of the North Sea, 2 yr averages (for statistics see Table 2)

Table 2. Test for differences of prevalences in areas (see Fig. 7), contingency tables, $\chi^{2}$ or Fisher's exact test for lower number (n). ns: not significant; $\mathrm{s}$ : significant; -: no infested cod caught in either area; p: 2-sided

\begin{tabular}{|c|c|c|c|c|c|}
\hline Date & Areas & Signif. & $x^{2}$ & $p$ & Fisher \\
\hline $82 / 83$ & $\begin{array}{l}1-2 \\
1-3 \\
1-4 \\
1-5 \\
1-6\end{array}$ & $\begin{array}{l}\mathrm{s} \\
\mathrm{ns} \\
\mathrm{ns} \\
\mathrm{ns} \\
\mathrm{ns}\end{array}$ & 5.578 & 0.0182 & \\
\hline $84 / 85$ & $\begin{array}{l}1-2 \\
1-3 \\
1-4 \\
1-5 \\
1-6\end{array}$ & $\begin{array}{l}\text { ns } \\
- \\
\text { s } \\
\text { s } \\
-\end{array}$ & $\begin{array}{l}8.032 \\
9.614\end{array}$ & $\begin{array}{l}0.0046 \\
0.0019\end{array}$ & \\
\hline $86 / 87$ & $\begin{array}{l}1-2 \\
1-3 \\
1-4 \\
1-5 \\
1-6\end{array}$ & $\begin{array}{l}\text { ns } \\
\text { ns } \\
\text { ns } \\
\text { ns } \\
\text { ns }\end{array}$ & & & $\begin{array}{l}+ \\
+ \\
+ \\
+ \\
+\end{array}$ \\
\hline $88 / 89$ & $\begin{array}{l}1-2 \\
1-3 \\
1-4 \\
1-5 \\
1-6\end{array}$ & $\begin{array}{l}\text { s } \\
\text { ns } \\
\text { ns } \\
\text { ns } \\
\text { s }\end{array}$ & 9.988 & $\begin{array}{l}0.0418 \\
00016\end{array}$ & + \\
\hline $90 / 91$ & $\begin{array}{l}1-2 \\
1-3 \\
1-4 \\
1-5 \\
1-6\end{array}$ & $\begin{array}{l}\text { ns } \\
\text { ns } \\
\text { ns } \\
\text { ns } \\
\text { ns }\end{array}$ & & & $\begin{array}{l}+ \\
+ \\
+ \\
+ \\
+\end{array}$ \\
\hline $92 / 93$ & $\begin{array}{l}1-2 \\
1-3 \\
1-4 \\
1-5 \\
1-6\end{array}$ & $\begin{array}{l}\mathrm{ns} \\
\mathrm{ns} \\
\mathrm{ns} \\
\mathrm{ns} \\
\mathrm{ns}\end{array}$ & & & $\begin{array}{l}+ \\
+ \\
+ \\
+ \\
+\end{array}$ \\
\hline
\end{tabular}

Catches of cod per hour and percentages of affected cod for 6 subareas in the North Sea from January 1982 to June 1993 are given in Fig. 6 (for size and location of areas see Fig. 7). With few exceptions, highest numbers of cod per hour were caught in Area 1 (German Bight), where numbers ( $\mathrm{n}$ ) decreased from $1188 \mathrm{~h}^{-1}$ in May 1982 to $17 \mathrm{~h}^{-1}$ in January 1988. In the period June 1989 to June 1992 summer catches fluctuated between 321 and $648 \mathrm{cod} \mathrm{h}^{-1}$, with catches in winter generally lower. Differences of catches between seasons were significant, with summer catches higher than winter catches (Mann-Whitney, 2-tailed: $p=0.0173$ ) There was a significant downward trend of catches of cod in Area 1 for winter data (linear model, $r=-0.6146, p=0.03345$ ) but no significant trend existed for the summer data and data for both seasons together. Elevated catches in the first year of the period studied were also found in Area 3. Differences of catches in Area 3 over time were significant (Kruskal-Wallis, $p<0.0001$ ). Catches in Area 1 differed significantly from those in Areas 3 to $6(\mathrm{p}<0.001)$ but not from Area 2. Also catches in Area 2 differed significantly from those of Area 3 $(p<0.05)$. All other differences were not significant (Dunn's multiple comparison test).

Trends in rates of infestation of cod in Area 1 reflect a similar fluctuation to that found for the total North Sea. Infestation rates around $1 \%$ during the first 3 cruises were followed by a period of 3 yr with zero infestation and increasing prevalences from January 1986 to January 1989 reaching a level of $5.6 \%$. A steep 

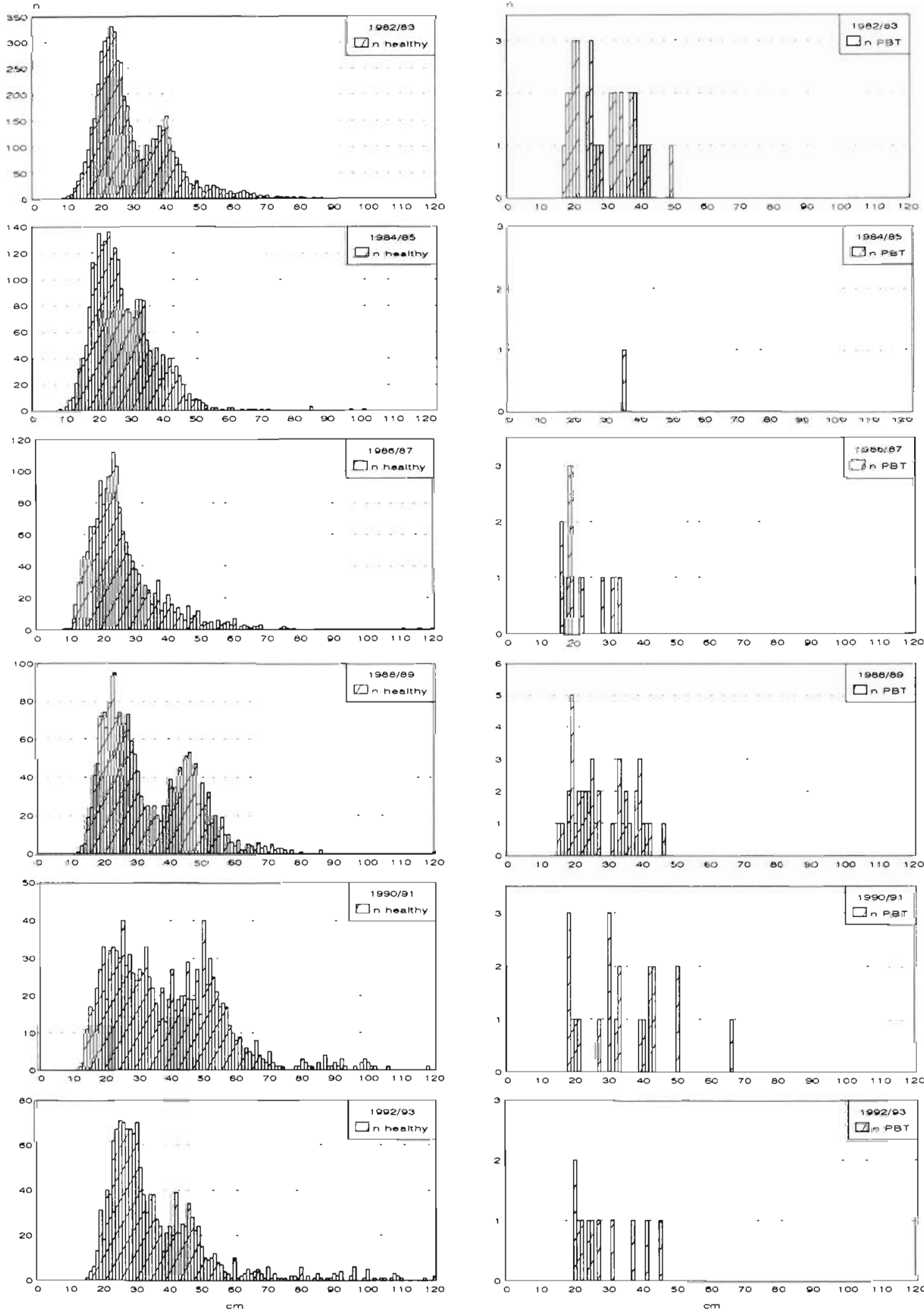

Fig. 8. Gadus morhua. Length frequencies of healthy cod and cod affected with PBT, 2 yr averages in the German Bight. $n$ : number (Area 1 in Fig. 7) 
Table 3. Gadus morhua, Iceland. Number investigated per station ( $\mathrm{n}$ invest); number caught per hour ( $\mathrm{n} \mathrm{h}^{-1}$ ); number aftected with pseudobranchial pseudotumours (n PBT)

\begin{tabular}{|c|c|c|c|c|c|c|c|c|c|c|c|}
\hline \multicolumn{4}{|c|}{1991} & \multicolumn{4}{|c|}{1992} & \multicolumn{4}{|c|}{1993} \\
\hline Stn & $\mathrm{n}$ invest & $\mathrm{n} \mathrm{h}^{-1}$ & $\mathrm{n} P B T$ & Stn & $\mathrm{n}$ invest & $n h^{-1}$ & $n \mathrm{PBT}$ & Stn & n invest & $\mathrm{n} \mathrm{h}^{-1}$ & $\mathrm{nPBT}$ \\
\hline 12 & 4 & 2 & 0 & 12 & 1 & 0 & 0 & 12 & 5 & 1 & 0 \\
\hline $12 \mathrm{a}$ & 0 & 0 & 0 & 13 & 3 & 1 & 0 & 13 & 10 & 2 & 0 \\
\hline 13 & 0 & 0 & 0 & 14 & 17 & 4 & 0 & 14 & 13 & 4 & 0 \\
\hline 14 & 17 & 4 & 0 & 16 & 37 & 12 & 0 & 16 & 5 & 11 & 0 \\
\hline 15 & 32 & 8 & 0 & 17 & 19 & 6 & 1 & 17 & 0 & 0 & 0 \\
\hline 16 & 8 & 7 & 0 & 18 & 0 & 0 & 0 & 18 & 0 & 0 & 0 \\
\hline 17 & 2 & 0.5 & 0 & 19 & 12 & 2 & 0 & 23 & 174 & 38 & 3 \\
\hline 18 & 0 & 0 & 0 & 20 & 151 & 100 & 0 & 24 & 799 & 160 & 47 \\
\hline \multirow[t]{4}{*}{19} & 14 & 11 & 0 & & & & & 25 & 113 & 26 & 9 \\
\hline & & & & & & & & 26 & 295 & 60 & 5 \\
\hline & & & & & & & & 27 & 247 & 45 & 12 \\
\hline & & & & & & & & 28 & 518 & 82 & 18 \\
\hline
\end{tabular}

decrease followed, reaching zero infestation in January 1991. In the period thereafter, the X-cell disease was present in the summers of 1991 and 1992, but was absent during all other cruises. For the other areas, different patterns were observed. There were no synchronized fluctuations of disease prevalences in the other areas. The regional distribution of affected cod ( 2 yr averages) according to the 6 areas as described above is given in Fig. 7. Distribution patterns as observed over the period studied were highly variable, indicating the regular occurrence of affected cod in 5 of the areas selected. In Area 3, affected cod were only detected during the cruise in June 1988. A test for differences of prevalences between areas (with Area 1 as reference) showed that most of the differences were not significant (Table 2).

In summary, it is obvious from Figs. $6 \& 7$ that there are conspicuous differences in the overall prevalence between years and areas but no trends could be stated. The length frequencies of healthy cod and affected cod in the German Bight (Area 1) for the 2 yr averages (size and location; Fig. 6) are depicted in Fig. 8. Generally, lengths of affected fish ranged from 15 to $46 \mathrm{~cm}$, in only 1 case was an affected fish larger than $50 \mathrm{~cm}$, and

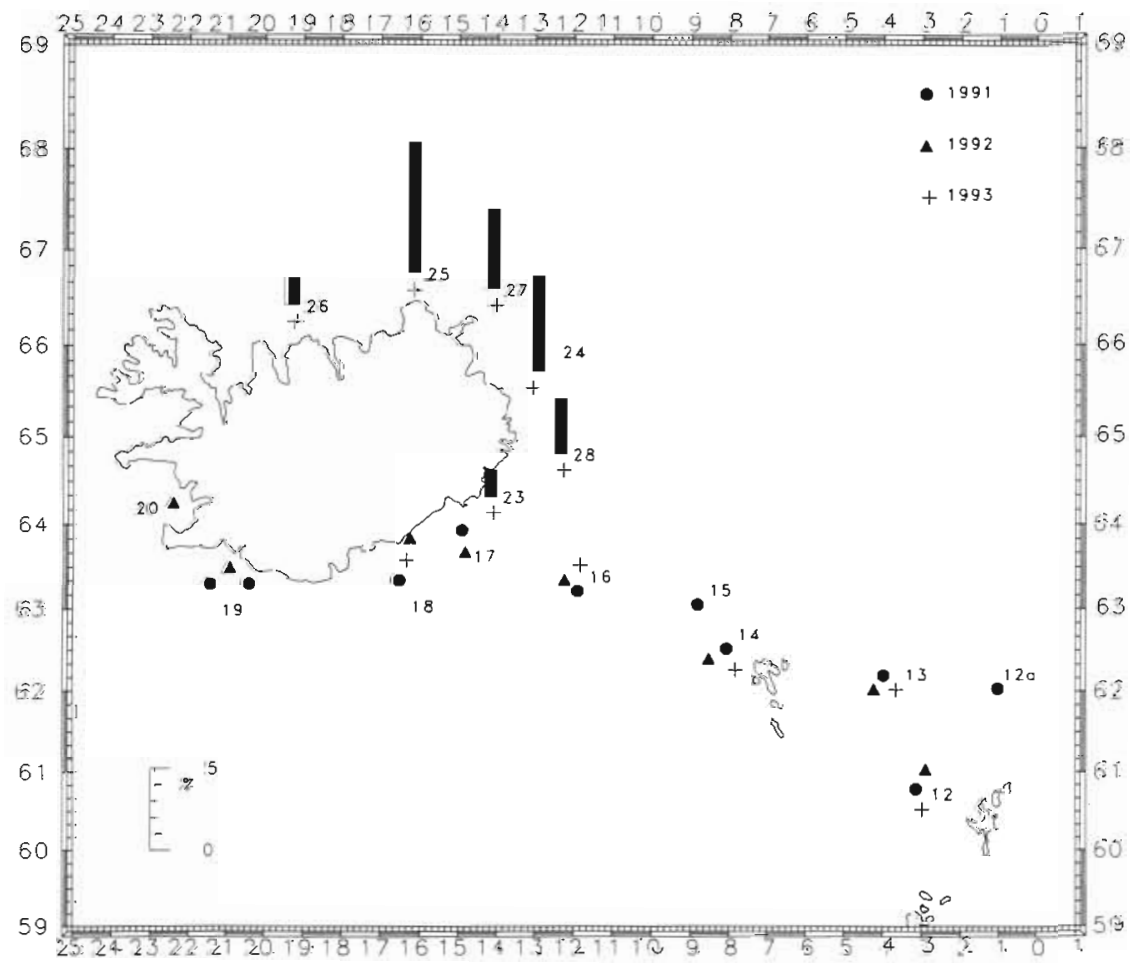

Fig. 9. Location of stations during cruises in 1991, 1992, 1993 and percentage of infestation of Gadus morhua with PBT in 1993 (for numbers see Table 3) 

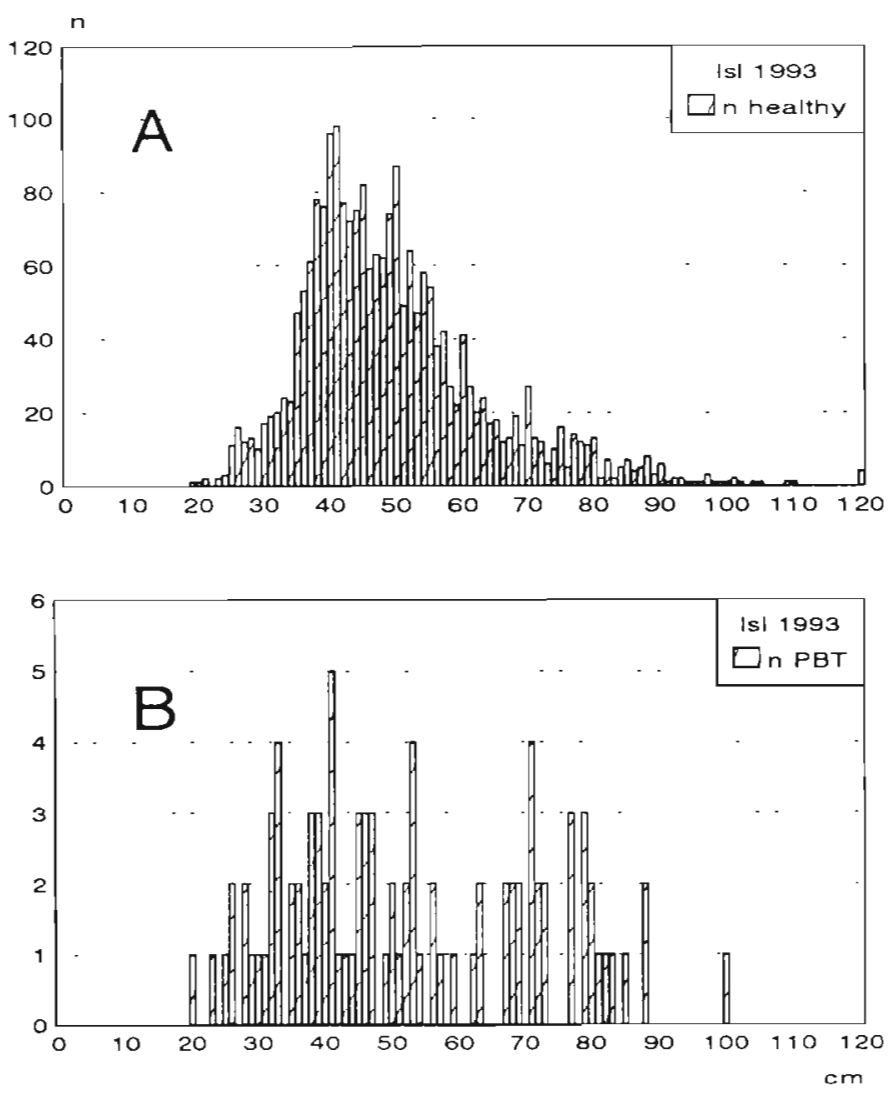

Fig. 10. Gadus morhua. Length frequencies of (A) healthy cod and (B) cod affected with PBT, Iceland, 1993 within this size range no further particular trend was visible (Fig. 8). The overall statistical analysis revealed that for the infestation of cod with $\mathrm{PBT}$, apart from season, all main effects were found to be significant (size: $\mathrm{p}<0.001$; area: $\mathrm{p}<0.05$; year: $p<0.001$ ). Some interactions were tested (areayear, season-year, season-area, season-size), but none proved to be significant.

Cruises west of the Faroe Islands and in nearshore areas off Iceland were performed in June 1991, 1992, and 1993. Cod with X-cell disease were found in 1992 (in Area 17, 1 cod out of 19; Table 3) and in 1993. Location of stations and infestation rates are depicted in Fig. 9.

Affected cod were exclusively found at stations to the southeast, east and northeast of Iceland. Prevalences ranged from 1.7 to $8.0 \%$. The differences of prevalences between the respective areas were significant $(p<0.01)$. Length frequencies of healthy cod and affected fish in 1993 are displayed in Fig. 10. Fish between 20 and $100 \mathrm{~cm}$ were afflicted, while rates of infestation of fish $70 \mathrm{~cm}$ and larger seemed to be higher than those with lengths between 40 and $50 \mathrm{~cm}$.

Age-length keys of diseased Icelandic cod in comparison to that of routinely aged fish from the respective area and season are given in Tables 4 \& 5. Cod affected with $X$-cell pseudotumours were significantly shorter (a difference of $\sim 18 \mathrm{~cm}$ ) than their healthy compatriots at all given ages

Table 4. Gadus morhua, Iceland. Age versus length of total and diseased fishes (in parentheses), data for diseased fishes from June 1993 and for total from July 1993 (data for total are from commercial catches, courtesy of Dr S. Schopka, Marine Research Institute, Reykjavik, Iceland)

\begin{tabular}{|c|c|c|c|c|c|c|c|c|c|c|c|c|c|c|}
\hline $\begin{array}{l}\text { Length } \\
(\mathrm{cm})\end{array}$ & Age: & 2 & 3 & 4 & 5 & 6 & 7 & 8 & 9 & 10 & 11 & 12 & 13 & 14 \\
\hline $25-29$ & & (1) & $(6)$ & & & & & & & & & & & \\
\hline $30-34$ & & & $(8)$ & (5) & & & & & & & & & & \\
\hline $35-39$ & & & (4) & (5) & & (1) & & & & & & & & \\
\hline $40-44$ & & 2 & $12(1)$ & (9) & (3) & & & & & & & & & \\
\hline $45-49$ & & & 49 & $8(9)$ & (1) & (1) & & & & & & & & \\
\hline $50-54$ & & & 57 & $25(3)$ & (2) & & $1(2)$ & & & & & & & \\
\hline $55-59$ & & 1 & 27 & $106(1)$ & $8(1)$ & 5 & & & & & & & & \\
\hline $60-64$ & & & 4 & 136 & 35 & $7(1)$ & & $3(1)$ & & & & & & \\
\hline $65-69$ & & & 2 & 67 & 77 & $27(1)$ & $2(1)$ & 3 & $1(5)$ & & & & & \\
\hline $70-74$ & & & & 14 & 62 & $72(1)$ & $13(1)$ & $1(1)$ & (6) & & & & & \\
\hline $75-79$ & & & & 4 & 33 & $78(1)$ & 41 & 7 & (3) & & & & & \\
\hline $80-84$ & & & & 2 & 8 & 33 & 42 & 21 & $8(5)$ & 3 & & & & \\
\hline $85-89$ & & & & & & 17 & 12 & 15 & $17(2)$ & 3 & & & & \\
\hline $90-94$ & & & & & 1 & 12 & 7 & 4 & 14 & 13 & & & & \\
\hline $95-99$ & & & & & & 1 & 2 & 3 & 10 & 7 & & & & \\
\hline $100-104$ & & & & & & & & & 7 & 8 & 1 & & & \\
\hline $105-109$ & & & & & & & & & 4 & 1 & & & & \\
\hline $110-114$ & & & & & & & & & & & & & & 1 \\
\hline $115-119$ & & & & & & & & & & & 1 & & & \\
\hline $125-129$ & & & & & & & & & & & 1 & & & \\
\hline
\end{tabular}


Table 5. Gadus morhua, Iceland. Age versus length of total and diseased fishes (parentheses), data for diseased fishes from June 1993 and for total from July 1993 (data for total are from scientific bottom trawls, courtesy of Dr J. Palsson, Marine Research Institute, Reykjavik, Iceland)

\begin{tabular}{|c|c|c|c|c|c|c|c|c|c|}
\hline $\begin{array}{l}\text { Length } \\
\text { (cm) }\end{array}$ & Age: & 2 & 3 & 4 & 5 & 6 & 7 & 8 & 9 \\
\hline $25-29$ & & (1) & (6) & & & & & & \\
\hline $30-34$ & & & (8) & (5) & & & & & \\
\hline $35-39$ & & 1 & $12(4)$ & (5) & 1 & (1) & & & \\
\hline $40-44$ & & & $19(1)$ & $6(9)$ & (3) & & & & \\
\hline $45-49$ & & & 5 & $15(9)$ & (1) & (1) & & & \\
\hline $50-54$ & & & 2 & $16(3)$ & $3(2)$ & & (2) & & \\
\hline $55-59$ & & & 1 & $13(1)$ & $2(1)$ & & & & \\
\hline $60-64$ & & & & 1 & 3 & (1) & & $1(1)$ & \\
\hline $65-69$ & & & & 1 & 3 & $4(1)$ & (1) & & (5) \\
\hline $70-74$ & & & & & 1 & $3(1)$ & (1) & (1) & (6) \\
\hline $75-79$ & & & & & & $3(1)$ & 1 & & (3) \\
\hline $80-84$ & & & & & & 2 & & & (5) \\
\hline $85-89$ & & & & & & & & & 1 (2) \\
\hline
\end{tabular}

North Sea. Prevalences encountered in the western Baltic Sea in the same time period were slightly lower, fluctuating between 0 and $2.4 \%$ (Dethlefsen \& Lang 1994). The prevalences varied within similar ranges in Norwegian waters (Egidius et al. 1981) and in Nova Scotia (Morrison et al. 1982), but were higher for Pacific cod off the west coast of Canada, with levels between 4.5 and $11.4 \%$ (Stich et al. 1976), and in the Bering Sea, with prevalences of $7.4 \%$ (Wellings et al. 1977). The X-cell disease of cod has hitherto not been described to occur in Icelandic waters aithough its presence in northern Icelandic fjords has recently been observed by local fishermen ( $R$. Bjönsdottir pers. comm.). Prevalences between 1 and $8 \%$ seemed to range in the $(p<0.001)$ (Table 4$)$. Growth differences were less pronounced but still significant $(p<0.01)$ when agelength data obtained from a scientific bottom trawl study were used for comparison (Table 5).

\section{DISCUSSION}

Macroscopic as well as microscopic characteristics of the lesions found in Icelandic cod correspond with those described by Watermann \& Dethlefsen (1982) for cod of the North Sea and the Baltic Sea, thus suggesting an identical etiology. The only striking difference can be seen in the fact that in Icelandic cod lytic or disintegrating stages were more frequent than previously described.

Although the $\mathrm{X}$-cell disease was first described to occur in cod of the North Sea in 1979 (Waterman et al. 1982), there is no reason to assume that this disease was new to this area. The fact that the PBT predominantly occur in the mouth cavity of affected fish could explain that they have been overlooked during earlier studies. Furthermore, historic studies on fish diseases in the North Sea such as those by Johnstone (1912. 1924,1925 ) concentrated on sporadic sampling but never covered wide areas.

During our studies and those by Watermann et al. (1982), relatively large numbers of cod were investigated, thereby increasing the possibility of finding the disease. Since 1979, affected cod have regularly been found in the German Bight and after 1981 in the North Sea within the geographical limits indicated above. The same holds for the western Baltic Sea (Dethlefsen \& Lang 1994). Over the period covered, the prevalences fluctuated between 0 and $4.6 \%$ in the area studied in the upper end as compared to occurrences in other marine areas. Reasons for the annual variability of disease prevalences in the North Sea and the German Bight are not known, but it is striking to note that maximum infestation rates in the German Bight of the North Sea were found to occur in January 1989 and in December 1988 in the western Baltic Sea. This indicates that an overriding factor may be triggering fluctuations of the disease. This has also been suggested by Möller (1981) to be the case for infectious diseases of dab in the North Sea.

Watermann et al. (1982) proposed that population densities play a dominant role in favouring the outbreak. For the 1993 Icelandic data, highest prevalence of X-cell pseudotumours was found in the area with the highest catch per hour (Area 25; Fig. 9) but a general density dependence could not be proven. In order to investigate the possibility of density dependence for the North Sea material the residuals from a model containing year, area and size group effects were pooled within year-area and plotted against the average catch $\left(\mathrm{n} \mathrm{h}^{-1}\right.$, excluding Group 0) obtained in that year and area. The plot (Fig. 11) does not show any positive trend of residuals with temporal/local densities, which could be expected if an effect existed.

Watermann et al. (1982) stated that in the German Bight predominantly year classes I through III were affected, with year classes I and II showing highest infestation rates of 10 and $16 \%$ This is in accordance with results from our own and other studies (Stich et al. 1976, Morrison et al. 1979). Stich et al. (1976) discussed whether a depressed respiration of affected Pacific cod could lead to retarded growth and delayed sexual maturity. Forrester (1969) found reduced growth and depressed maturation in Pacific cod off the west coast of North America. McCain et al. (1979) reported a 


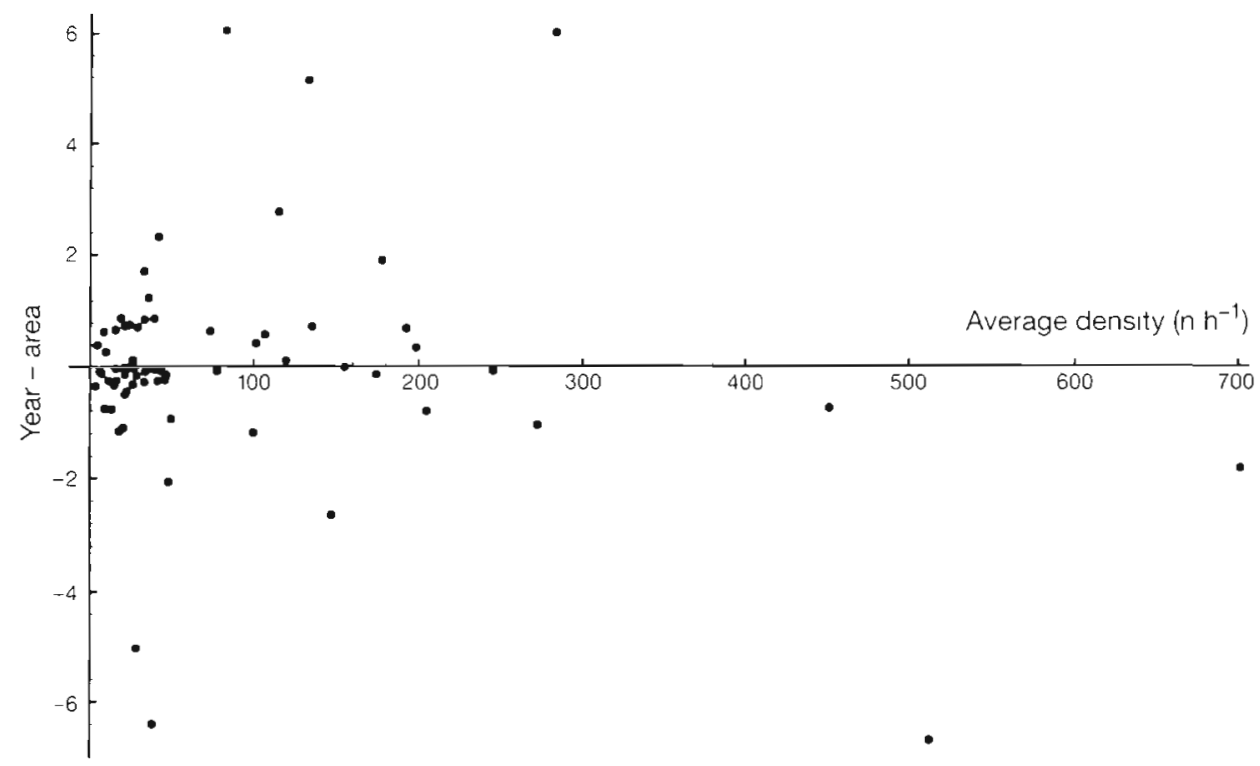

Fig. 11 Gadus morhua. North Sea, pooled residuals (observed versus expected numbers of affected individuals) within year-area versus average density $\left(\mathrm{n} \mathrm{h}^{-1}\right)$ in year-area similar age-length relationship for normal and diseased cod of Alaskan waters. In contrast the growth rate of walleye pollock Theragra chalcogramma with pseudotumours was depressed, 15\% shorter than their healthy cohorts at 3 to 5 yr of age (McCain et al. 1979). Similar observations are given in reports on Pacific flatfish afflicted with epidermal tumours (Stich et al. 1977). Blue whiting Micromesistius potassu from Norwegian waters with pseudobranchial pseudotumours also showed a reduced growth and lower weight in relation to their healthy cohorts (Egidius \& Monstad 1982). Dorsch (1981) found a retardation of growth of pseudotumour-bearing cod from the German Bight of 1 to $6 \mathrm{~cm}$ in Group I, 13 to $22 \mathrm{~cm}$ in Group II and 21 to $25 \mathrm{~cm}$ in Group III. According to our own hitherto unpublished material the growth reduction of afflicted specimens in the North Sea amounted to 4 to $6 \mathrm{~cm}$ for the different age groups, based on material from 1981 and 1982 .

Knust \& Dethlefsen (1986) found that North Sea dab Limanda limanda with X-cells in their gills were 2 to 5 yr old and their condition and their gonadosomatic index were reduced as compared to healthy specimens. These X-cells in dab display the same histological features as those found in PBT indicating the same origin. The retarded growth of affected Icelandic cod as compared to that of healthy specimens can be taken as a further indication of a physiological impact of the disease.

Watermann et al. (1982) suggested, based on differences in length distributions of affected and nonaffected fish, that a disease-induced mortality might exist, but would be difficult to prove due to the fact that cod is heavily fished in the German Bight. Campana (1984) found temperature related mortalities in starry flounders Platichthys stellatus afflicted with X-cell tumours. The situation with Icelandic cod is difficult to interpret. Length distribution of affected fishes also showed the presence of the disease in larger fishes, which does not indicate an elevated mortality by infestation despite the obviously retarded growth of affected cad. One possibility is that larger fish may have been affected only recently so that the impact of the infestation has not yet been lethal.

Watermann et al. (1982), regarding epidemiological data, stated that the distribution of diseased cod in the German Bight reflects their annual migration patterns. In January of the respective years, affected cod were concentrated in the centre of the Bight, and in spring, after the beginning of their migration, they were found to be dispersed over a much wider area. From our results no further facts can be deduced to support this statement, largely because we sampled a wider station grid on only 2 occasions per year.

A conspicuous disease in an economically important fish species certainly presents a problem for the marketability of that fish. For German fisheries it can be stated that presently, due to low infestation rates, the disease is irrelevant in this context. For Icelandic fisheries with an average infestation rate of $4.4 \%$ in cod of the northeastern population the situation is different. Externally visible signs of the disease in the head region of the fish will probably be removed by processing but the retardation in growth as found in afflicted specimens deserves further study. This is necessary because in this study the material for age-length readings of healthy and diseased fishes was not obtained on the same occasion. The question of whether volume and developmental stage of X-cell pseudotumours is correlated with the reduction of growth needs 
further elucidation. Given the fact that X-cell diseases in fishes are widespread and occasionally present in high prevalences, their currently unknown etiology also needs to be studied

Acknowledgements. Thanks to W. Wosniok, Bremen, for statıstical advice, to S. Ehrich, Mrs M. Schröder, Hamburg, and J. Palsson, Reykjavik, for reading otoliths of affected cod; to captains and crews of the research vessels 'Anton Dohrn', 'Walther Herwig' and 'Walther Herwig III'; to S. Schopka, Reykjavik, for providing an age-length key for cod from northeastern Icelandic waters for comparison; and to $\mathrm{N}$. Peters, Hamburg, J. Palsson, Reykjavik, A. H. McVicar, Aberdeen and 2 anonymous reviewers for critically reading the manuscript.

\section{LITERATURE CITED}

Anders K, Möller $H$ (1991) Atlas der Fischkrankheiten im Wattenmeer. Forschungsbericht 10204373/1. Im Auftr des Umweltbundesamtes. Erich Schmidt, Berlin, p 1-112

Campana SE (1.984) Mortality of starry flounders (Platichthys stellatus) with skin tumours. Can J Fish Aquat Sci 40: 200-207

Dethlefsen V. Lang T (1994) Fischkrankheiten in der Ostsee. Infn Fischw 41(2):92-101

Dorsch K (1981) Pseudobranchialtumoren beim Kabeljau in der Nordsee (Gadus morhua). Diplomarbeit, Universität Hamburg

Egidius ED, Johannessen JV, Lange E (1981) Pseudobranchial tumour in Atlantic cod, Gadus morhua L., from the Barents Sea. J Fish Dis 4:527-532

Egidius ED, Monstad P (1982) Pseudobranchial tumours in blue whiting from Norwegian waters. ICES Comm Meet (Pelagic Fish Comm) E:16

Forrester CR (1969) Life history information on some groundfish species. Fish Res Bd Can Tech Rep 105:1-17

Johnstone NJ (1912) Internal parasites and diseased conditions of fishes. Proc Trans Liverpool Biol Soc 26:103-144

Johnstone NJ (1924) Diseased conditions in fishes. Proc Trans Liverpool Biol Soc 38:183-213

Johnstone NJ (1925) Malignant tumours in fishes. Proc Trans Liverpool Biol Soc 39:169-200

Knust R, Dethlefsen V (1986) X-cells in gills of North Sea dab (Limanda limanda L.), epizootiology and impact on condition. Arch FischWiss 37(1/2):11-24

Responsible Subject Editor: N. Peters, Hamburg, Germany
Lange $E$ (1973) Carcinoid-like tumours in the pseudobranch of Gadus morhua. Comp Biochem Physiol 45(A):477-481

McCain BB, Gronlund WD, Myers MS, Wellings SR (1979) Tumours and microbial diseases of marine fishes in Alaskan waters. J Fish Dis 2:11-130

McCullagh P, Nelder JA (1983) Generalized linear models. Chapman and Hall, London

Möller H (1981) Fish diseases in German and Danish coastal waters in summer 1980. Meeresforsch 29:1-16

Morrison CM, Appy RG, Shum G, Annand C, Odense P (1979) Histology and the incidence of pseudobranch tumours in Atlantic cod (Gadus morhua) in Halifax Harbour. ICES Comm Meet (Pelagic Fish Comm) E:31

Morrison CM, Shum G, Appy RG, Odensee PH, Annand C (1982) Histology and prevalence of X-cell lesions in Atlantic cod (Gadus morhua). Can J Fish Aquat Sci 39:1519-1530

Peters N (1984) Diseases caused by neoplasia. In: Kinne O (ed) Diseases of marine animals, Vol IV, Part 1. Biologische Anstalt Helgoland, Hamburng. p 400-423

Peyron A. Thomas L (1929) Contribution à l'étude des tumeurs du revêtement branchial chez les poissons. Bull Assoc Fr Etude Cancer 18:825-827

Romeis B (1989) Mikroskopische Technik. 17, neubearb Auflage. Böck P (ed) Urban und Schwarzenberg, München

Stich HF, Acton AB, Forrester CR (1976) Fish tumors and sublethal effects of pollutants. J Fish Res Bd Can 33:1993-2001

Stich HF, Acton AB, Oishi K, Yamazaki F, Harada T, Hibino T, Moser HG (1977) Systematic collaborative studies on neoplasms in marine animals as related to the environment. In: Kraybill HF, Dawe CJ, Harshbarger JC, Tardiff RG (eds) Aquatic pollutants and biological effects with emphasis on neoplasia. Ann NY Acad Sci 298:374-388

Takashima F, Hibiya T (1995) An atlas of fish histology, 2nd edn. Kodansha, Tokyo

Watermann B, Dethlefsen V (1982) Histology of pseudobranchial tumours in Atlantic cod (Gadus morhua) from the North Sea and the Baltic Sea. Helgoländer Meeresunters 35:231-242

Watermann B, Dethlefsen V, Hoppenheit M (1982) Epidemiology of pseudobranchial tumours in Atlantic cod (Gadus morhual from the North Sea and the Baltic Sea. Helgoländer Meeresunters 35:425-437

Watermann B, Egidius E, Peters N, Schmidt W (1994) Occurrence and structure of cysts in X-cell lesions of Atlantic cod (Gadus morhua L.). ICES Comm Meet (Pelagic Fish Comm) E:12

Wellings SR, Alpers CE, McCain BB, Myers MS (1977) Fish disease in the Bering Sea. Ann NY Acad Sci 298:290-304

Manuscript first received: September 6, 1995

Revised version accepted: November 17, 1995 